\title{
The role of ADAMTS genes in preeclampsia
}

\section{ADAMTS genlerinin preeklampside rolü}

\author{
İrem Eda Gökdemir1, Özlem Evliyaoğlu², Buğra Çoşkun³ \\ 1 Yenimahalle Training and Research Hospital, Clinic of Obstetrics and Gynecology, Ankara, Turkey \\ 2Zekai Tahir Burak Women's Health Training and Research Hospital, Clinic of Obstetrics and Gynecology, Ankara, Turkey \\ ${ }^{3}$ Dr. Nafiz Körez Sincan State Hospital, Clinic of Obstetrics and Gynecology, Ankara, Turkey
}

\begin{abstract}
Preeclampsia is a complex disease that increases both maternal and fetal morbidity and mortality in both developed and developing countries. It complicates around $5-10 \%$ of all pregnancies.. The pathophysiology of preeclampsia includes both maternal and fetal/placental factors. Implantation of embryo and placentation are crucial steps for development of pregnancy involving trophoblast invasion. Abnormalities of spiral artery invasion, trophoblast function, inflammatory process, and biologic functions of angiogenic/anti-angiogenic factors early in pregnancy result in pregnancy diseases, including preeclampsia. ADAMTS genes are members of the family of matrix metalloproteinase, which have important tasks in extracellular matrix (ECM) degradation and repair processes. The roles of ADAMTS in preeclampsia may include regulation of spiral artery invasion and ECM arrangement of the placenta.
\end{abstract}

Keywords: ADAMTS genes, placentation, preeclampsia

\section{$\ddot{\mathrm{O} z}$}

Preeklampsi, gelişmiş ve gelişmekte olan ülkelerde maternal ve fetal morbidite ve mortaliteyi arttıran kompleks bir hastalıktır. Gebeliklerin \%5-10'unu komplike eder. Maternal, fetal ve plasental faktörler preeklampsi patofizyolojisinde rol oynarlar. Trofoblast invazyonu, embriyo implantasyonu ve plasentasyon gebelik gelişimi için kritik aşamalardır. Anormal gelişen spiral arter invazyonu, trofoblast fonksiyonu, enflamatuvar süreç ve erken gebelik döneminde anjiyogenik/anti-anjiyogenik faktörlerin biyolojik fonksiyonları preeklampsi gibi gebelikle ilişkili hastalıkların oluşmasına neden olur. ADAMTS, ekstraselüler matriksin (ECM) degradasyonu ve tamir aşamalarında önemli görev yapan matriks metalloproteinaz ailesinin üyesidir. ADAMTS'lerin preeklampsideki rolü, spiral arterlerin invazyonu ve plasentada ECM'nin regülasyonu olabilir.

Anahtar Kelimeler: ADAMTS genleri, plasentasyon, preeklampsi

\section{Introduction}

Preeclampsia is defined as the clinical condition associated with hypertension (systolic blood pressure $\geq 140 \mathrm{~mm} \mathrm{Hg}$ or diastolic blood pressure $\geq 90 \mathrm{~mm} \mathrm{Hg}$ ) and proteinuria or end-organ dysfunction in a woman who was normotensive before 20 weeks gestation $(1,2)$. Hypertensive diseases in pregnancy account for $16 \%$ of maternal deaths in developed countries(1). According to data in the United States in 2010, $12 \%$ of pregnancy-associated maternal deaths are due to preeclampsia and eclampsia(1). The main characteristics of hypertensive disorders and fetal growth restriction in pregnancy are gestation-specific restructuring of spiral arteries and defects in trophoblastic invasion(3-5). In normal implantation, highly invasive trophoblast cells migrate to the decidua and myometrium and invade the endothelium of spiral arteries along with the muscularis tunica media. Smooth muscle structures at the distal part of uterine spiral arteries disappear. Terminal branches of the uterine artery transform into vessels that bear high capacity and low resistance, and provide the blood flow needed for development of the placenta $(6,7)$. Although gestation-specific restructuring of the spiral arteries begins at the end of the first trimester and is completed by the 18-20th weeks, it is not known when trophoblastic invasion is terminated. Although they infiltrate the decidual spiral arteries, cytotrophoblasts cannot penetrate into the myometrium and pseudovasculogenesis does not occur $(8,9)$. This in turn leads to undesirable conditions such as placental hypoperfusion, placental infarction and atherosclerosis, fetal demise during the second trimester, placental abruption, preeclampsia, intrauterine growth restriction (IUGR), preterm labor, and premature rupture of membranes $(1,10,11)$. Invasion of spiral arteries by trophoblasts, release of special matrix metalloproteinases, and embodiment of the extracellular matrix (ECM) structure are necessary(12). ECM has an active role in

Address for Correspondence/Yazışma Adresi: İrem Eda Gökdemir, MD,

Yenimahalle Training and Research Hospital, Clinic of Obstetrics and Gynecology, Ankara, Turkey

E-mail: fornostt@yahoo.com

Received/Geliș Tarihi: 10.04.2016 Accepted/Kabul Tarihi: 17.08.2016

OTurkish Journal of Obstetrics and Gynecology, Published by Galenos Publishing House.

This article is distributed under the terms of the "Creative Commons Attribution NonCommercial 4.0 International Licence (CC BY-NC 4.0)". 
regulating cellular activity and behaviors such as shaping the cell, differentiation, division and programmed cell death. Matrix metalloproteinases are a member of the ADAM and ADAMTS zinc-dependent proteinases family. ADAMTS degrade molecules that act on regulation of the tissue microenvironment. Some of these molecules belong to the ECM (collagen, proteoglycan, and many other glycoproteins), and others do not (receptors, growth factors, and cytokines). It was shown that spiral artery invasion was limited in preeclampsia (Figure 1).

Changes in the ECM in the placentas and umbilical cords of the pregnant women with preeclampsia are different than those in normal pregnancies; however, the etiology is not yet clear(13-15). The roles of cellular adhesion molecules, angiogenic proteins, and the inflammation system on microvascular dysfunction are undeniable in patients with preeclampsia(16). Impairment of trophoblastic cell differentiation accounts for the inability of spiral arteries to invade into trophoblasts. Cytokines, adhesion molecules, ECM metalloproteinases, and class $1 \mathrm{~b}$ major histocompatibility complex molecules released during trophoblastic invasion of endothelial cells and changes in HLA-G expression act on trophoblast differentiation $(17,18)$.

Preeclampsia can result in maternal complications such as eclampsia, edema, hypertensive encephalopathy, stroke, kidney and liver failure, liver rupture, retinal detachment, blindness, disseminated intravascular coagulation, and death(19); and fetal outcomes such as IUGR, oligohydramnios, asphyxia, prematurity, preterm labor, and perinatal death. Studies on biological markers are needed in order to understand the etiology of this disease and predict preeclampsia.

ADAMTS genes were discovered in 1997 and were first defined by Kuno et al.(20) as associated with colon cancer and inflammation. ADAMTS proteinases currently involve many physiologic and pathologic processes such as the those of the female reproductive system (Figure 2)(21,22).

ADAMTS play a role in events such as restructuring of tissue, coagulation, angiogenesis, degradation of the ECM and basal membrane, and tumoral cell invasion and metastasis $(23,24)$. ADAMTS should be expressed, and the ECM must be degraded and formed so that trophoblasts can invade maternal tissues and spiral arteries. Invasion of the ECM is provided by the release of complicated proteases. ADAMTS-1, -2, -4, -6, -7, -9, and -12 subtypes are expressed during the first trimester in human placenta(25). In addition, ADAMTS-1, -4, -5, -6, -7, -9, and -10 mRNA expressions were detected in term placenta(26-30). Therefore, it is important to interpret the molecular organization and function of ADAMTS.

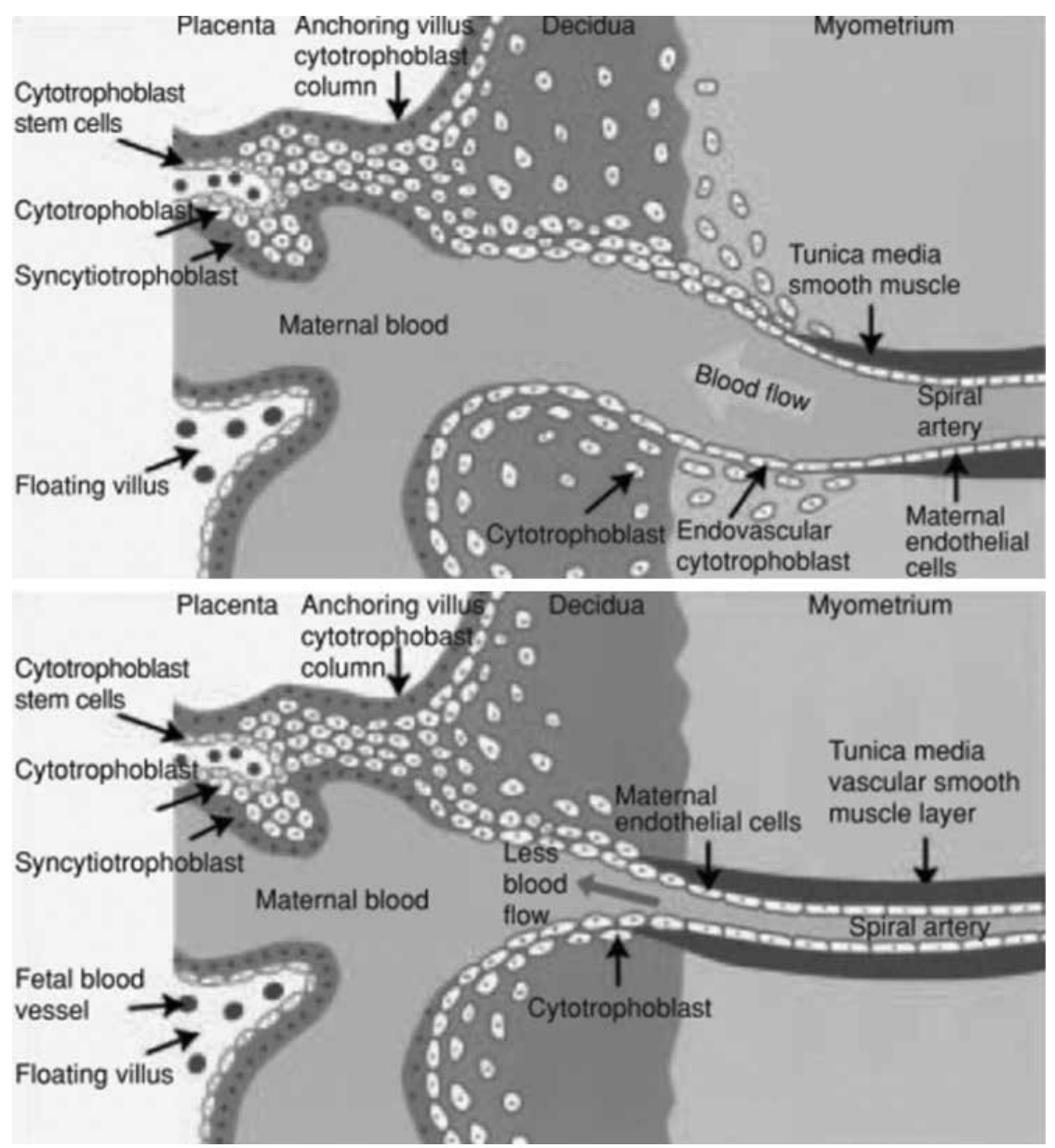

Figure 1. Normal placentation-pseudovasculogenesis (upper panel) and abnormal placentation in preeclampsia (lower panel)(11) 
ADAM-12 is among factors that predict preeclampsia(1). One of two types of ADAM-12 is secreted (ADAM-12s), which interferes with the function of insulin-like growth factorbinding protein 3 (IGFBP-3) and IGFBP-5, which in turn leads to the development of preeclampsia(31). The difference between ADAMTS and ADAM is the thrombospondin (TSP) portion, which resides at the molecular level. TSP is the ECM adhesion glycoprotein secreted from thrombocytes and is an angiogenesis inhibitor(32). ADAMTS-12 is expressed in precedence by extravillous trophoblasts as compared with other ADAMTS(33). Independent from the proteolytic activity of the enzyme, loss or decrease of ADAMTS-12 function diminishes the trophoblastic invasion. ADAMTS-12 regulates the cell invasion by regulating the av $\beta 3$ integrin heterodimer function and expression, and controls the trophoblast invasion by affecting the in vitro level of ADAMTS-12-transforming growth factor- $\beta 1$ and interleukin$1 \beta(33)$. As a result, compared with other ADAMTS, ADAMTS-12 is secreted in precedence from the placental tissues and increases the invasion of trophoblasts. Deficiency of ADAMTS enzymes leads to several pregnancy complications, mainly preeclampsia. Eda Gokdemir et al.(34) provided evidence that ADAMTS-12 levels were significantly decreased in the serum of patients with preeclampsia. Deficiency of ADAMTS-12 may cause defective trophoblast differentiation, abnormal remodeling of spiral arteries, and abnormal development of the placenta, which induces preeclampsia. Thus, ADAMTS proteinases play crucial roles in a variety of normal and pathophysiologic processes of placentation (Figure 3).
Daglar et al.(35) studied placental levels of ADAMTS-12 to determine whether levels of enzymes differed among early-onset and late-onset severe preeclampsia. Early-onset preeclampsia was more likely associated with placental factors in impaired implantation and invasion than maternal factors. However, there were no significant differences in ADAMTS-12 levels between the groups. Also, ADAMTS genes are associated with other diseases such as ovarian cancer, polycystic ovarian syndrome, and premature ovarian failure $(36,37)$. These genes play multiple roles in male and female fertility(38).

\section{Result}

Preeclampsia is one of the important complications of pregnancy. Early prediction of the disease is crucial in order to prevent maternal and fetal morbidity and mortality. A simple, cost-effective test performed in pregnant women with high-risk of developing preeclampsia would have significant effects on maternal and fetal morbidity and mortality of this disease. In ADAMTS function deficiency, impairments in differentiation of trophoblasts, invasion of spiral arteries, angiogenesis, and ECM restructuring ensue. Implantation failure can lead to abortion, preterm labor, early membrane rupture, pregnancy-associated hypertensive diseases, and preeclampsia.

\section{Conclusion}

ADAMTS genes are potential candidates in the pathophysiology of preeclampsia. Further studies are needed to determine whether these molecules can predict preeclampsia.

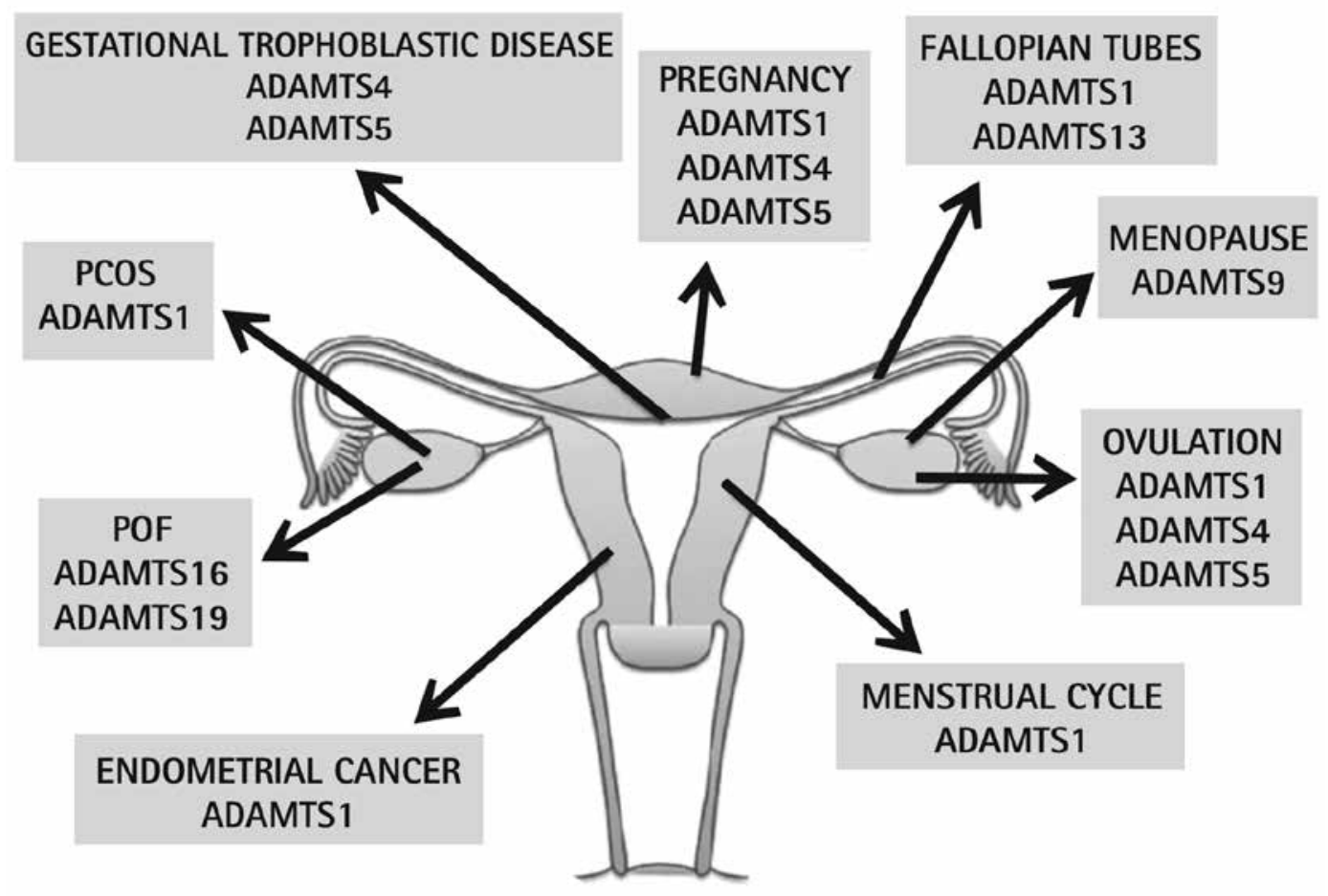

Figure 2. The role of the ADAMTS: A new biological marker candidates in physiological and pathological processes in female reproductive $\operatorname{system}^{(22)}$ 


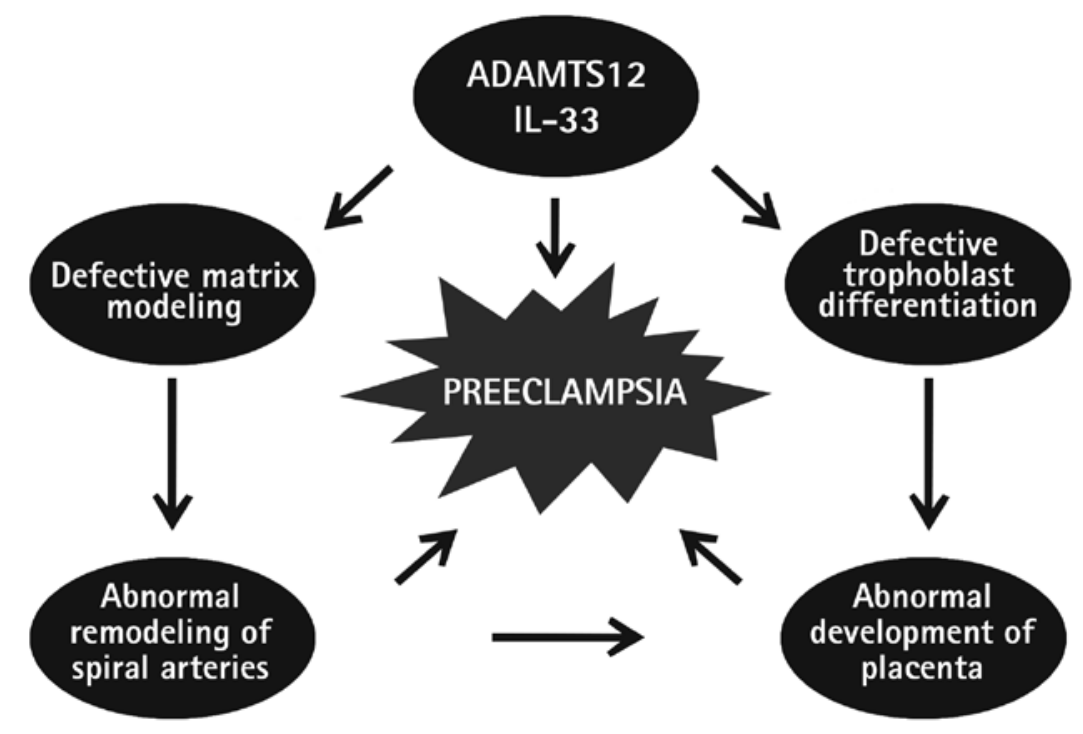

Figure 3. Deficiency of ADAMTS-12 may cause defective trophoblast differentiation and matrix reshaping, abnormal remodeling of spiral arteries and finally abnormal development of the placenta that induce preeclampsia(34)

\section{IL: Interleukin}

\section{Ethics}

Peer-review: Externally peer-reviewed.

\section{Authorship Contributions}

Surgical and Medical Practices: İrem Eda Gökdemir, Concept: İrem Eda Gökdemir, Buğra Çoşkun, Design: Buğra Çoşkun, Data Collection or Processing: Özlem Evliyaoğlu, Analysis or Interpretation: İrem Eda Gökdemir, Özlem Evliyaoğlu, Literature Search: İrem Eda Gökdemir, Özlem Evliyaoğlu, Writing: İrem Eda Gökdemir, Buğra Çoşkun.

Conflict of Interest: No conflict of interest was declared by the authors.

Financial Disclosure: The authors declared that this study received no financial support.

\section{References}

1. Cunningham FG. Hypertensive Disorders. In: F. Gary Cunningham, Kenneth J. Leveno, Steven L. Bloom, et al., editors. Williams Obstetrics. 24th ed. New York, McGraw-Hill-2014;728-79.

2. American College of O, Gynecologists, Task Force on Hypertension in P. Hypertension in pregnancy. Report of the American College of Obstetricians and Gynecologists' Task Force on Hypertension in Pregnancy. Obstet Gynecol 2013;122:1122-31.

3. Kaufmann P, Black S, Huppertz B. Endovascular trophoblast invasion: implications for the pathogenesis of intrauterine growth retardation and preeclampsia. Biol Reprod 2003;69:1-7.

4. Pijnenborg R, Vercruysse L, Hanssens M. The uterine spiral arteries in human pregnancy: facts and controversies. Placenta 2006;27:93958.

5. Çırpan T, Akercan F, Coşan Terek F, Özçakır HT, Giray G, Sağol $S$, et al. Evaluation of VEGF, EGF-R AND TGF- $\alpha$ in placenta of pregnancies with preeclampsia by immunohistochemistry. Turk J Obstet Gynecol 2008;5.
6. Zhou Y, Damsky CH, Fisher SJ. Preeclampsia is associated with failure of human cytotrophoblasts to mimic a vascular adhesion phenotype. One cause of defective endovascular invasion in this syndrome? J Clin Invest 1997;99:2152-64.

7. Zhou Y, Damsky CH, Chiu K, Roberts JM, Fisher SJ. Preeclampsia is associated with abnormal expression of adhesion molecules by invasive cytotrophoblasts. J Clin Invest 1993;91:950-60.

8. Roberts JM, Redman CW. Pre-eclampsia: more than pregnancyinduced hypertension. Lancet 1993;341:1447-51.

9. Meekins JW, Pijnenborg R, Hanssens M, McFadyen IR, van Asshe A. A study of placental bed spiral arteries and trophoblast invasion in normal and severe pre-eclamptic pregnancies. Br J Obstet Gynaecol 1994;101:669-74.

10. Brosens I, Pijnenborg R, Vercruysse L, Romero R. The "Great Obstetrical Syndromes" are associated with disorders of deep placentation. Am J Obstet Gynecol 2011;204:193-201.

11. Karumanchi SA, Maynard SE, Stillman IE, Epstein FH, Sukhatme VP. Preeclampsia: a renal perspective. Kidney Int 2005;67:2101-13.

12. Hu WT, Li MQ, Liu W, Jin LP, Li DJ, Zhu XY. IL-33 enhances proliferation and invasiveness of decidual stromal cells by upregulation of CCL2/CCR2 via NF-kappaB and ERK1/2 signaling. Mol Hum Reprod 2014;20:358-72.

13. Carson DD, Bagchi I, Dey SK, Enders AC, Fazleabas AT, Lessey BA, et al. Embryo implantation. Dev Biol 2000;223:217-37.

14. Crispi F, Llurba E, Dominguez C, Martin-Gallan P, Cabero L, Gratacos E. Predictive value of angiogenic factors and uterine artery Doppler for early- versus late-onset pre-eclampsia and intrauterine growth restriction. Ultrasound Obstet Gynecol 2008;31:303-9.

15. Salomon C, Yee SW, Mitchell MD, Rice GE. The possible role of extravillous trophoblast-derived exosomes on the uterine spiral arterial remodeling under both normal and pathological conditions. Biomed Res Int 2014;2014:693157.

16. Sibai BM. Preeclampsia: an inflammatory syndrome? Am J Obstet Gynecol 2004;191:1061-2.

17. Cross JC, Werb Z, Fisher SJ. Implantation and the placenta: key pieces of the development puzzle. Science 1994;266:1508-18. 
18. Lim KH, Zhou Y, Janatpour M, McMaster M, Bass K, Chun SH, et al. Human cytotrophoblast differentiation/invasion is abnormal in preeclampsia. Am J Pathol 1997;151:1809-18.

19. Magee LA, Yong PJ, Espinosa V, Cote AM, Chen I, von Dadelszen P. Expectant management of severe preeclampsia remote from term: a structured systematic review. Hypertens Pregnancy 2009;28:312-47.

20. Kuno K, Kanada N, Nakashima E, Fujiki F, Ichimura F, Matsushima K. Molecular cloning of a gene encoding a new type of metalloproteinasedisintegrin family protein with thrombospondin motifs as an inflammation associated gene. J Biol Chem 1997;272:556-62.

21. Apte SS. A disintegrin-like and metalloprotease (reprolysin-type) with thrombospondin type 1 motif (ADAMTS) superfamily: functions and mechanisms. J Biol Chem 2009;284:31493-7.

22. Demircan K, Comertoglu I, Akyol S, Yigitoglu BN, Sarikaya E. A new biological marker candidate in female reproductive system diseases: Matrix metalloproteinase with thrombospondin motifs (ADAMTS). J Turk Ger Gynecol Assoc 2014;15:250-5.

23. Tortorella MD, Malfait F, Barve RA, Shieh HS, Malfait AM. A review of the ADAMTS family, pharmaceutical targets of the future. Curr Pharm Des 2009; 15:2359-74.

24. Demircan K, Akyol S, Armutcu F. A Multi-Functional Gene Family From Arthritis to Cancer: A Disintegrin-Like Metalloproteinase with Thrombospondin Type-1 Motif (ADAMTS). J Clin Anal Med 2013;4.

25. Lee SY, Lee HS, Gil M, Kim CJ, Lee YH, Kim KR, et al. Differential expression patterns of a disintegrin and metalloproteinase with thrombospondin motifs (ADAMTS) $-1,-4,-5$, and -14 in human placenta and gestational trophoblastic diseases. Arch Pathol Lab Med 2014;138:643-50

26. Abbaszade I, Liu RQ, Yang F, Rosenfeld SA, Ross OH, Link JR, et al. Cloning and characterization of ADAMTS11, an aggrecanase from the ADAMTS family. J Biol Chem 1999;274:23443-50.

27. Hurskainen TL, Hirohata S, Seldin MF, Apte SS. ADAM-TS5, ADAMTS6, and ADAM-TS7, novel members of a new family of zinc metalloproteases. General features and genomic distribution of the ADAM-TS family. J Biol Chem 1999;274:25555-63.
28. Llamazares M, Cal S, Quesada V, Lopez-Otin C. Identification and characterization of ADAMTS-20 defines a novel subfamily of metalloproteinases-disintegrins with multiple thrombospondin-1 repeats and a unique GON domain. J Biol Chem 2003;278:13382-9.

29. Somerville RP, Longpre JM, Jungers KA, Engle JM, Ross M, Evanko S, et al. Characterization of ADAMTS-9 and ADAMTS-20 as a distinct ADAMTS subfamily related to Caenorhabditis elegans GON-1. J Biol Chem 2003;278:9503-13.

30. Somerville RP, Jungers KA, Apte SS. Discovery and characterization of a novel, widely expressed metalloprotease, ADAMTS10, and its proteolytic activation. J Biol Chem 2004;279:51208-17.

31. Laigaard J, Sorensen T, Placing S, Holck P, Frohlich C, Wojdemann $\mathrm{KR}$, et al. Reduction of the disintegrin and metalloprotease ADAM12 in preeclampsia. Obstet Gynecol 2005;106:144-9.

32. Baenziger NL, Brodie GN, Majerus PW. A thrombin-sensitive protein of human platelet membranes. Proc Natl Acad Sci U S A 1971;68:240-3.

33. Beristain AG, Zhu H, Leung PC. Regulated expression of ADAMTS-12 in human trophoblastic cells: a role for ADAMTS-12 in epithelial cell invasion? PLoS One 2011;6:e18473.

34. Eda Gokdemir I, Ozdegirmenci O, Elmas B, Sarikaya E, Tokmak A, Kazanci FH, et al. Evaluation of ADAMTS12, ADAMTS16, ADAMTS18 and IL-33 serum levels in pre-eclampsia. J Matern Fetal Neonatal Med 2016;29:2451-6.

35. Daglar K, Kirbas A, Timur H, Ozturk Inal Z, Danisman N. Placental levels of total oxidative and anti-oxidative status, ADAMTS-12 and decorin in early- and late-onset severe preeclampsia. J Matern Fetal Neonatal Med 2016:1-6.

36. Lima MA, da Silva SV, Freitas VM. Progesterone acts via the progesterone receptor to induce adamts proteases in ovarian cancer cells. J Ovarian Res 2016;9:9.

37. Xiao S, Li Y, Li T, Chen M, Xu Y, Wen Y, et al. Evidence for decreased expression of ADAMTS-1 associated with impaired oocyte quality in PCOS patients. J Clin Endocrinol Metab 2014;99:E1015-21.

38. Russell DL, Brown HM, Dunning KR. ADAMTS proteases in fertility. Matrix Biol 2015;44-46:54-63. 